\title{
SENYAWA GLIKOSIDA SEBAGAI BAHAN FARMASI POTENSIAL SECARA KINETIK
}

\author{
Laode Rijai \\ Research and Development Pharmaceutical Laboratory of FARMAKA TROPIS \\ Pharmacy Faculty, University of Mulawarman, Samarinda, East Kalimantan, Indonesia \\ laode@farmasi.unmul.ac.id
}

\begin{abstract}
ABSTRAK
Kinetika molekul xenobiotik dalam sel dipengaruhi reseptor enzim dan non-enzim serta sifat fisiko-kimia dari molekul xenobiotik dan reseptor tersebut. Sifat fisik lipiditas reseptor sangat berpengaruh terhadap kinetika sehingga berakibat pada laju molekul dalam proses pembentukan efek dinamik maupun eliminasi. Rata-rata manusia mengandung 42 liter air yang menempati 3 liter dalam darah dan 39 liter dalam sel. Aqua atau air tersebut sebagai media transport metabolisme baik itu anabolisme maupun katabolisme metabolit dalam sel. Kandungan air dalam sel menyebabkan sifat lipiditas reseptor sangat rendah atau memiliki sifat aqua sangat tinggi. Senyawa glikosida memiliki sifat sangat polar mendekati air hingga menyerupai sifat lipiditas aqua. Sifat fisika sangat polar yang dimiliki oleh senyawa glikosida mempermudah penyerapan dalam sel sehingga memiliki laju pembentukan efek dinamik maupun eliminasi yang baik. Dengan demikian senyawa glikosida sangat potensial sebagai bahan farmasi jika ditinjau dari kinetika.
\end{abstract}

Kata Kunci: Senyawa Glikosida; bahan farmasi, kinetika

\section{PENDAHULUAN}

Molekuler yang terlibat dalam sistem metabolisme atau pembetukan dan penguraian molekul-molekul dalam sel mahluk hidup yang lazim adalah protein, karbohidrat, asam nukleat, dan lipid lemak dan kolesterol. Molekuler ini banyak kalangan menyebutnya biomolekular karena berperan dalam sistem mahluk hidup. Seluruh metabolit tersebut terbentuk dan terurai dalam sel dengan bahan baku suplai dari luar tubuh yang disebut dengan makanan. Selain keempat golongan tersebut terdapat mikronutrien seperti vitamin, ion-ion dalam bentuk makro dan mikro mineral dan non-mineral dari suplai luar tubuh, tetapi wajib tetap tersedia dalam sel tersebut. Fungsi umum seluruh zat makanan tersebut adalah untuk pertumbuhan, pertahanan proses metabolisme, perbaikan metabolit (regenerasi), dan sumber energi. Protein misalnya berperan sebagai penyusun jaringan dengan cara polimerisasi molekul asam amino, selain itu sebagai penyusun enzim, penyusun asam-asaman, dan berbagai metabolit lainnya. Metabolisme yaitu pembentukan dan penguraian molekul dalam sel berupa pertumbuhan, regenerasi sel, proses pernapasan, pencernaan, dan lain sebagainya. Proses tersebut berlangsung secara terus menerus yang digambarkan oleh kerja berbagai organ seperti jantung, paru-paru, hati dan lain sebagainya. Kekurangan atau kelebihan salah satu metabolit dalam waktu tertentu dapat menyebabkan kerusakan organik, sedangkan kekeliruan proses metabolisme sebagai akibat respon enzim terhadap psikologi sel disebut dengan kerusakan fungsional. Kerusakan organik dan fungsional saling terkait yang dapat menyebakan peningkatan kerusakan 
organik maupun sistem (fungsional) sesuai fungsi waktu.

Molekul-molekul kimia reseptor dalam sel berperan sebagai penerima molekul asing untuk tujuan stimulan, perlindungan, regenerasi, dan pertumbuhan dalam sistem metabolisme inter dan intra sel. Molekul-molekul tersebut dapat berupa enzim, hormon, dan non keduanya. Molekul reseptor tersebut yang akan berperan dalam menerima dan memberikan reaksi terhadap molekul asing (xenobiotik) seperti obat. Molekul obat harus melintasi berbagai sistem metabolisme dalam sel yang memiliki sifat fisika dan kimia yang spefisik, dan kedua sifat tersebut mempengaruhi perjalanan xenobiotik untuk mencapai penerima atau reseptor dan juga untuk mencapai eliminasi atau penghilangan dari sistem metebolisme. Dengan demikian pengetahuan seorang perancang obat harus memahami secara paripurna tentang struktur molekul reseptor dan bahan aktif obat untuk meramalkan kejadian sifat kimia dan fisika antara kedua molekular tersebut sehingga efek kimia, fisika, dan biologi dapat diramal. Sifat kimia reseptor dan molekul obat membantu memprediksi interaksi kimia yang akan terjadi yang akan menghasilkan efek biologi dalam sistem metabolisme, sedangkan sifat fisika resptor serta jaringan yang dilewati oleh molekuler obat sangat menentukan laju perjalanan molekul obat tersebut.

Salah satu sifat fisika yang berperan terhadap laju perjalanan molekul obat dalam sistem metabolisme yang melintasi berbagai lapisan yang mengandung sejumlah metabolit yang memiliki karakteristik tertentu, termasuk sifat fisika. Istilah yang banyak digunakan terkait dengan kinetika molekul obat dalam sistem metabolisme adalah hidrofil dan hidrofob. Hidrofil berarti suka air (aqua) dan hidofob suka lipid atau tidak suka air. Berbagai jaringan yang tersusun secara sistematis molekul penyusunya akan menghasilkan sifat fisika yang unik dan spesifik terkait dengan tingkat kesukaan terhadap air tersebut. Jaringan kulit misalnya dirancang sedimikian rupa memiliki tingkat ketidaksukaan air sehingga air dan mineral tidak dapat masuk dalam jaringan, yang bukan disebabkan oleh pori-pori tetapi disebabkan perbedaan sifat fisik (lipiditas) antara jaringan kulit dengan air dan mineral tersebut. Perihal inilah yang menyebabkan penggunaan teknik injeksi (menembus jaringan kulit) untuk memasukan molekul obat yang tidak dapat terabsorbsi oleh jaringan kulit maupuan pencernaan (perjalanan metabolit primer dalam sel).

Senyawa glikosida memiliki sifat aqua yang signifikan sehingga memudahkan perjalanannya dalam sistem metabolisme karena sel manusia mengandung 42 liter air dan 3 liter di antaranya merupakan pelarut subtansial untuk darah. Sifat ini akan mempercepat perjalanan suatu molekuler untuk mencapai reseptor maupun untuk eliminasi. Senyawa glikosida yang memiliki dua kutub berlawanan yaitu polar dan nol-polar namun secara total memiliki sifat polaritas yang tinggi. Dengan demikian molekul glikosida berpotensial sebagai bahan farmasi terutama obat jika ditinjau dari kinetika dalam sistem metabolisme.

\section{METODE}

Kajian artikel ini merupakan hasil review berbagai hasil-hasil penelitian dan buku referens terkait dengan glikosida dan biokimia. Dengan demikian metode kajian yang dilakukan adalah:

a. Penelusuran referens tentang glikosida terutama terkait dengan sifat fisikokimia yang dimiliki oleh molekul tersebut.

b. Penelusuran penggunaan glikosida alami sebagai bahan farmasi terutama obat

Berdasarkan hasil-hasil kajian tersebut, makan dirumuskan tentang potensi yang dimiliki oleh glikosida dalam bidang farmasi, khususnya tinjauan 
kinetika atau laju perjalanan molekul dalam sel hingga eliminasi.

\section{HASIL DAN PEMBAHASAN}

\section{a. Glikosida}

Glikosida adalah senyawa alami yang terdiri dari bagian karbohidrat dan bagian bukan karbohidrat. Bagian bukan karbohidrat paling banyak ditemukan adalah triterpen, steroid, dan flavanoid; sedangkan molekul karbohidrat yang<smiles>CC(C)CC(C)C1CCC2(C)CCC3C(CCC4C5(C)CCC(C6CCCCC6)C(C)(C)C5CCC34Cl)C2C1</smiles>

Glikosida triterpen Tipe Oleana<smiles>CC1(C)C(Cl)CCC2(C)C1CCC1(Cl)C3CCCC3CCC21</smiles>

Glikosida Steroid

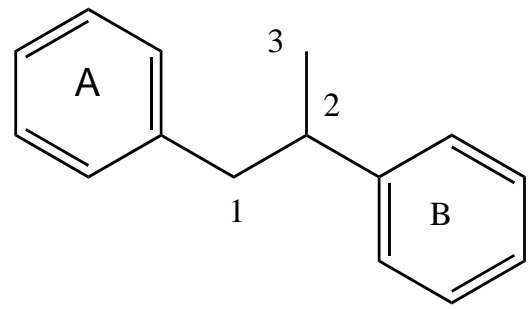

Isoflavanoid (1,2-diarilpropana) paling banyak ditemukan adalah glukosa, galaktosa, xilosa, dan arabinosa. Monosakarida tersebut dapat terikat pada satu atau lebih atom $\mathrm{C}$ pada bagian bukan karbohidrat. Kata glikosida bermakna karbohidrat atau gula yang umumnya bersifat oksidator yang disebut dengan glikon, sedangkan bukan gula disebut dengan aglikon. Ikatan kimia bentukan glikosida menyerupai eter sehingga secara kimiawi dalam proses pembentukannya selalu melepaskan air atau $\mathrm{H}_{2} \mathrm{O}$.<smiles>CC1(C)C(Cl)CCC2(C)C1CCC1(Cl)C3CCC4CCCC4C3CCC21</smiles>

Glikosida triterpen Tipe Lpeol<smiles>IC(CCc1ccccc1)c1ccccc1</smiles>

KERANGKA INTI KIMIA FLAVANOID (1,3 - Diarilpropana)<smiles>CCC(c1ccccc1)c1ccccc1</smiles>

Neoflavanoid (1,1-Diarilpropana) 


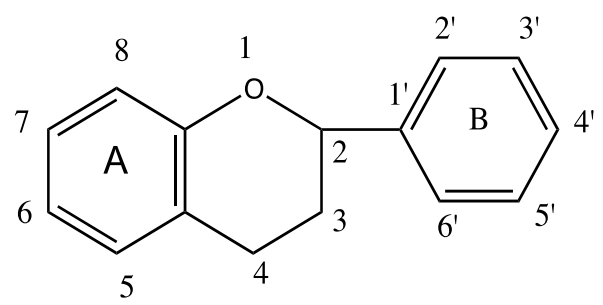

\section{FLANOID TERBANYAK}

Gambar 1. Kerangka Inti Aglikon Senyawa Glikosida

Senyawa lain glikosida adalah glikosianogen yang cukup berbahaya karena dengan proses mekanik dapat terurai membentuk asam sianida $(\mathrm{HCN})$ yang memiliki sifat reaktif dengan oksigen sehingga masuk kategori senyawa mematikan. Oleh karena itu glikosianogen tidak termasuk senyawa potensial dalam bidang farmasi yang memiliki reaktivitas tinggi. Seluruh senyawa glikosida tersebut terutama glikosida steroid dan triterpen pada umumnya bersifat antimikrobaa karena memiliki sifat tegangan permukaan yang disebabkan oleh adanya dua kutub polar dan non-polar yang dapat merusak dinding sel mikroba dan menyebabkan kematian mikroba itu sendiri, meskipun tidak semua mikroba. Namun demikian letak gugus karbohidrat juga menentukan sifat tersebut sehingga senyawa glikosida tidak seluruhnya memiliki aktivitas antimikroba yaitu dipengaruhi letak gugus karbohidrat tersebut.

\section{b. Bioaktivitas Biologi Glikosida}

Senyawa glikosida terbanyak di alam adalah saponin (glikosidasteroid, glikosidatriterpen) dan glikosidaflavanoid. Kedua golongan senyawa ini yang paling menonjol aktivitas biologisnya disebabkan glikosida adalah saponin yaitu peninggkatan jumlah aktivitas aglikon setelah menjadi glikosida hingga $100 \%$ dari jenis aktivitas biologi sebelumnya (Hostetman, 1993). Selanjutnya, untuk glikosida flavanoid meluasnya spektrum aktivitas biologi disebabkan oleh inti kimia yang dimiliki yaitu flavanoid, isoflavanoid, dan neoflavanoid serta hetersiklik yang dibentuk. Glikosida flavanoid hanya meningkat polaritas sehingg menjadi lebih baik kinetika dalam sel dengan mengabaikan kerja resepter secara kimia tetapi secara fisika. Bioaktivitas dasar yang selalu dimiliki kedua glikosida tersebut adalah antimikroba untuk glikosida steroid dan triterpen, sedangkan glikosida flavanoid pada umumnya adalah antioksidan. Kedua sifat ini berperan dalam sistem metabolisme terutama stimulan dan perlindungan antigen. Mekanisme kerja antioksidan selalu bersifat stimulo yaitu meningkatkan normalisasi metabolisme dan mencegah gangguan invasi kimia dari luar, sedangkan glikosida steroid dan triterpen juga memiliki aktivitas stimulo melalu kerja hormon (sinyal kimia proses) dan juga keamanan terhadap antigen khusunya gangguan mikroba. Dengan demikian potensi bioaktivitas kedua golongan senyawa glikosida tersebut sangat penting dalam bidang farmasi.

\section{c. Kinetika Glikosida dalam Metabolisme}

Absorbsi suatu senyawa dalam sistem metabolisme ditentukan sifat fisika dan kimia yaitu tergantung pada sifat jaringan anatomi sel yang dilewati. Jaringan kulit misalnya memiliki sifat lipiditas yang sangat spesifik setiap lapisan sehingga sifat fisika seperti polaritas tidak dapat menembus jaringan tersebut. 
Rancangan membran jaringan kulit yang luar biasa tersebut menjadi berperan sebagai pelindung dari berbagai gangguan luar sehingga kulit pantas disebut dengan pelindung. Nano partikel hingga super nano bukan persyaratan utama untuk menembus jaringan kulit, karena selain sifat fisika sebagai penentu untuk menembus jaringan kulit juga terdapat sifat kimia yang menolak senyawa asing akan melewatinya. Oleh karena itu sistem pemberian senyawa xenobiotik untuk tujuan pengobatan hanya memiliki dua cara yaitu oral atau menembus jaringan kulit untuk masuk dalam media transportasi yaitu darah untuk selanjutnya menuju pada molekul-molekul reseptor yang juga memiliki sifat fisiko-kimia yang spesifik.

Senyawa glikosida bersifat sangat polar sehingga secara teori mudah terabsorbsi dalam sel, yang didominasi oleh sistem polar karena presentase jumlah air yang sangat dominan. Namun demikian sistem enzim yang bertugas untuk mencegah atau membantu perjalanan suatu xenobiotik dalam sel, senyawa glikosidapun akan mengalami berbagai hambatan dalam melintasi sistem metabolisme. Senyawa glikosida yang merupakan senyawa alami pasti terdapat sejumlah enzim yang berperan sebagai katabolis ataupun anabolis atau hanya membantu perjalanan xenobiotik tersebut. Namun demikian masuknya xenobiotik terutama melalui oral akan melewati sistem pencernaan yang mempunyai enzim spesifik misalnya spesifik katabolis untuk protein, karbohidrat, dan lemak; dan di luar ketiga golongan senyawa tersebut termasuk xenobiotik. Secara ikatan kimia, senyata glikosida terbentuk dengan ikatan glikosida (-O-) sehingga secara teori akan terdapat enzim yang mengkatabolis senyawa glikosida tersebut, terutama dalam sistem pencernaan karbohidrat. Namun demikian secara kimia suatu ikatan dipengaruhi oleh kedudukan gugus lain termasuk ikatan kimia baik itu secara sterik maupun induksi. Oleh karena itu senyawa glikosida ditinjau dari segi sifat fisika polaritas sangat memungkinkan perjalanannya dalam sistem metabolisme menjadi lebih mudah.

Senyawa glikosida yang dapat masuk dalam sistem aliran darah sebagai media transportasi akan mudah mencapai reseptor karena mudah terabsorpsi oleh sel jaringan yang juga didominasi oleh aqua atau air atau bersifat hidrofil. Untuk sistem oral masih disangsikan dapat terhidrolisis oleh enzim maltase terutama glukosidase, jika bagian karbohidrat tersebut adalah glukosa, tetapi untuk karbohidrat lain seperti galatose, arabinosa, xilosa,memungkin dapat masuk dalam sistem peredaran darah. Dengan demikian senyawa glikosida jika memiliki aktivitas biologi terkait dengan potensi kefarmasian sangat potensial ditinjau dari segi kinetika karena dapat mudah terabsorbsi dalam sel. Khusus glikosida yang mengandung karbohidrat glukosa masih memungkinkan terhidrolisis dalam sistem pencernaan jika melalui oral, sehingga akan menjadi lebih melalui jaringan kulit.

\section{KESIMPULAN}

1. Senyawa glikosida secara kinetika sangat potensial sebagai bahan farmasi karena bersifat sangat polar yang mudah terabsorbsi dalam sistem metabolisme

2. Glikosida yang mengandung glukosa disarankan untuk dilindungi dalam bentuk sediaan jika digunakan secara oral, dan lebih melalui jaringan kulit

3. Seluruh glikosida memiliki aktivitas biologi sehingga disebut dengan senyawa potensial dalam bidang farmasi

\section{REKOMENDASI}

Diperlukan penelitian kinetika secara invivo dengan aglikon yang berbeda dan glikon yang sama, demikian pula aglikon yang sama dan glikon yang berbeda. 
DAFTAR PUSTAKA

1. Maria C., L., 1998, Nutrition Biochemistry and Metabolism, ACS. Syngapore

2. Martin, L., 1984., Secondary Metabolism in Plants, Microorganisms, and Animals (second. Ed), Springer Verlag, Tokyo
3. Rijai, L., 2004. Saponin dari Biji Chydenenthus excelsus., DISERTASI, UNPAD, Bandung 